\title{
SZÁMNEVET TARTALMAZÓ FRAZEOLÓGIAI EGYSÉGEK A SZERB ÉS A MAGYAR NYELVBEN***
}

\begin{abstract}
A tanulmányban olyan szerb frazeológiai egységek kerülnek feldolgozásra, amelyeknek számnévi alaptagjuk van, azzal a céllal, hogy megkeressük magyar nyelvü ekvivalenseiket, illetve hiányukban szó szerinti fordítást adunk. Ezenkívül a szólások néhány szemantikai jellemzőjére is rámutatunk, amelyek alapján csoportokba soroljuk őket. Az elemzés alapján azt a következtetést lehet levonni, hogy léteznek szólások, amelyek formájuk és jelentésük tekintetében mindkét nyelvben megegyeznek, de vannak olyanok is, amelyeknél a lexikai szerkezet módosul, illetve olyan szerb frazémák is előfordulnak, amelyeknek nincs megfelelöjük a magyarban.
\end{abstract}

Kulcsszavak: frazeológia, számok, szerb nyelv, magyar nyelv

\section{BEVEZETÉS}

Egy nyelv frazeológiai kincse nagymértékben kultúraspecifikus, a nyelvet beszélö közösség hagyományában gyökerezö álláspontokat, értékeket, hiedelmeket tükrözi. A frazeológiai egységek különböző nyelvekben történő kontrasztív viszgálata hozzájárul ahhoz, hogy az azonosságok és eltérések megállapítása révén betekintést nyerjünk a különböző nyelvközösségbe tartozó beszélők világképébe és valóságszemléletébe, illetve az általuk képviselt kultúrmodellek jellemzőibe. Ugyanis, az emberi gondolkodást befolyásoló univerzális modellek mellett a

\footnotetext{
*andrice@ff.uns.ac.rs

** A tanulmány a Szerb Köztársaság Oktatási, Tudományi és Technológiai Fejlesztésügyi Minisztériuma által támogatott két projektum keretében készült. Az egyik a 178004 számú Sintaksička, semantička i pragmatička istraživanja standardnog srpskog jezika (A szerb sztenderd nyelv mondattani, jelentéstani és pragmatikai kutatásai), a másik pedig a 178002 számú Jezici i kulture u vremenu i prostoru (Nyelvek és kultúrák időben és térben) címü projektum.
} 
szólások megalkotásában nagy szerepet játszanak a kultúra elemei, használatukat pedig a kontextus, illetve a konkrét kommunikációs szituáció szabja meg. ${ }^{1}$

A szerb és a magyar nyelv, mint ismeretes, tipológiailag (is) különbözik egymástól, de több évszázados területi egymás mellett élésük és művelődési kapcsolatuk nyoma világosan tetten érhető. Ugyanakkor várható, hogy mindkét vizsgált nyelv magán viseli kulturális jellemzőit, különösen a frazeológia terén. Ezért úgy döntöttünk, hogy a szerb nyelvből kiidulva megvizsgáljuk, léteznek-e ekvivalens kifejezések a magyarban, és amennyiben nincs megfelelő szólás a célnyelvben, körülíró fordítást alkalmazunk. Ezúttal a számnévi alaptagot tartalmazó frazeológiai egységeket jelöltük ki vizsgálatunk tárgyául.

A továbbikban két szerb frazeológiai szótárból (Matešić 1982, és Otašević 2012) és a szerb értelmező szótárból (RSJ) kijegyzetelt példákat mutatjuk be szemantikai körük alapján csoportosítva őket. ${ }^{2}$ A szövegben a frazeológiai egységeket magyar értelmezésük követi, utánuk az esetleges magyar ekvivalensek következnek dőlt betükkel szedve. A magyar megfelelők meglétét és szemantikáját Forgács Tamás (Forgács 2003) és Bárdosi Vilmos (Bárdosi 2012) frazeológiai szótárában ellenőriztük. A lábjegyzetben, ha szükséges, a szerb szólások szó szerinti fordítását adjuk meg.

\section{TŐSZÁMOK A FRAZEOLÓGIÁBAN}

Ha az 1-től 10-ig terjedő tőszámokat vesszük szemügyre, a szerbben a legtöbb frazéma az egyes számmal keletkezett, gyakorisági sorrendben második helyen a kettes áll, harmadik helyen a négyes, ezt követi az ötös, majd a hármas, a kilences, a hetes és a tízes. A nyolcassal egy frazémát sem tartanak számon, a hatos

${ }^{1}$ A frazeológiai egységeket különböző elméleti és módszertani megközelítéssel lehet vizsgálni. G. Štrbac (2019) áttekinti a legújabb nyelvészeti irányzatokat, amelyek a frazeológiai kutatások során alkalmazhatóak, különösen kiemelve a kognitív nyelvészeti, a lingvokulturális és a pragmatikai irányzatokat. Míg az első a szólásalkotás általános kognitív mechanizmusaival foglalkozik, addig a második a kulturális befolyások szerepét hangúlyozza, a harmadik pedig a frazémahasználatot meghatározó kontextuális motívumokat és szabályokat vizsgálja. E szerint a felosztás szerint a mi kutatásunk elsősorban lingvokulturális irányultságú.

2 A frazeológiai egységek bemutatásakor a témával kapcsolatos korábbi kutatások eredményeire (Fink, 1989, Mršević-Radović 1994, és Ajdačić 2015) alapoztunk. 
pedig csak egy példában található meg: ni pet ni šest ${ }^{3}$, a jelentése 'azonnal, rögtön, habozás, gondolkodás nélkül'.

A jedan 'egy' számot tartalmazó frazeologizmusok igen különbőző jelentésekben fordulnak elő, lehetnek pozitív, negatív és semleges értéküek. Gyakran olyan helyzetet jelölnek, amelyben több különböző személy együttesen és egyidejüleg lép fel:

iz jednog glasa ${ }^{4}$ - egyhangúan, egyöntetüen, erőteljesen, közösen egy emberként

jednim glasom ${ }^{5}$ - 1. egyidejüleg beszélve, egyik a másikat túlharsogva 2. együttesen, közös erővel, egyetértve 3. egyértelmüleg, közakarattal jednim grlom $^{6}$ - egyhangon

jedan za sve, svi za jednog - kölcsönös feláldozás jeléül Egy mindenkiért, mindenki egyért.

Amennyiben a frazeologizmus egyetértést, harmóniát, közösséget jelent, ez az egység pozitív értékü, mint az alábbi példákban:

biti jedno telo i jedna duša - teljes egyetértésben, harmóniában élnek; azonos nézeteket vallanak, azonosan gondolkodnak/éreznek Egy test, egy lélek.

ići pod jedan konac ${ }^{7}$ - együttmüködnek valamiben, megértik egymást, egy véleményen vannak egy kézre dolgoznak, egy kerékvágásban jár valakivel, egy nyelven beszél, egy nótát fúj

jesti/lomiti s kim jednu pogaču ${ }^{8}$ - együtt élnek, megértésben él valakivel egy fedél alatt él valakivel, egy kenyéren él valakivel

jednodušni kao jedan` - egyként, összetartva egy szívvel-lélekkel

dva tela a jedna duša - harmóniában, szerelemben élnek két test egy lélek.

\footnotetext{
${ }^{3}$ Sem öt, sem hat.

${ }^{4}$ Egy hangból.

${ }^{5}$ Egy hanggal.

${ }^{6}$ Egy torokból.

${ }^{7}$ Egy cérna alá mennek.

${ }^{8}$ Egy lepényt eszik/tör vkivel.

${ }^{9}$ Egylelküek egyként.
} 
Az együttlét, közösségvállalás negatív előjelü is lehet, pl. amikor valamely önző érdeket szolgáló, kényes vagy vitatható ügyben valaki azonos álláspontra helyezkedik valakivel, ugyanazt teszi, gondolja, mint a másik, a kegyeibe akar férkőzni, ezért ugyanúgy cselekszik, valakinek a pártját fogja:

duvati/puhati u jednu/istu tikvu/rog/duduk ${ }^{10}$ - egy húron pendül valakivel, egy követ fúj valakivel, egy lantot penget, egy gyékényen árul/árulnak vkivel.

Negatív értékkel bírnak azok a frazeologizmusok is, amelyek a különböző dolgok alaptalan kiegyenlítését hivatottak kifejezni, amikor valaki különböző jellegü személyeket vagy dolgokat helytelenül összetartozónak vagy azonosnak tekint, azonos módon ítél meg, összekever, kiegyenlít, tévesen azonosít vagy túlzottan általánosít:

stavljati/staviti pod jednu kapu ${ }^{11}$ - egy kalap alá vesz

strpati/trpati sve u jedan lonac ${ }^{12}$ - mindent összekever, nem különbözteti meg a dolgokat

trpati/strpati sve na/u jednu gomilu ${ }^{13}$ - egyenlőnek, azonosnak tekinti azt, ami összeegyeztethetetlen.

A jedan sokszor elégtelen is lehet, kevesebb a kívánatosnál, valamiből nagyon kevés, alig néhány van:

moći se na prste jedne ruke prebrojiti/nabrojiti - egy kézen/egyik kezén is megszámolhatja

jedna lasta ne čini proleće - egy fecske nem csinál nyarat jedan $i$ (kao) nijedan ${ }^{14}$ - egyetlen ember nem sokat jelent.

Erre a magyaban nincs teljes mértékben ekvivalens példa, de van egy hasonló, amely csak a gyerekvállalásra vonatkozik: egy gyerek nem gyerek.

\footnotetext{
${ }^{10}$ Egy tökbe/kürtbe/dudába fújnak.

${ }^{11}$ Egy sapka alá tesz.

${ }^{12}$ Egy fazékba töm.

${ }^{13}$ Egy halomba gyüjt.

${ }^{14}$ Egy (akár/mint) egy sem.
} 
nijelnema ni na/za jedan zub ${ }^{15}$ - nagyon kevés, túl kevés, elégtelen egy gyüszüre való, csak egy csepp a tengerben, egy kávéskanálnyi, a fél fogára sem (volt) elég

vagy ha éppen ugyanazon képet szeretnénk felidézni a 'fog' kifejezésünkkel, akkor: vkinek eggyel több füle van mint foga.

Ugyanakkor egyetlen ember, az egyén elegendő is lehet: jedan, ali vredan ${ }^{16}$ - egy ember is sokat tehet vmilyen ügyben.

S ha már a mennyiségnél tartunk, akkor a 'senki' ellentétét, a másik végletet (a 'mindenki' jelentésében) az alábbi kifejezéspár fejezi ki a szerbben, illetve magyarban is:

svi do jednoga - mind egy szálig, egytöl egyig (kivétel nélkül mind).

Az egyes szám az összevont, rövid fogalmazásmódot is jelölheti a frazémákban:

jednim slovom ${ }^{17}$ - egyszóval, röviden és világosan

jednom reči/rečju - röviden elmondva, összegezve, egyszóval.

Olyan frazeologizmusokban is jelentkezik, amelyek rövid időintervallumot, periódust jelölnek, vagy pedig váratlan megjelenést, gyorsaságot jelentenek:

u jedan $\mathrm{mah}^{18}$ - azonnal, egyszerre

$u$ jedan tren $^{19}$ - nagyon gyorsan, pillanatok alatt, azonnal, egyszerre egy miatyánk/egy szempillantás alatt

u jednom dahu - nagyon gyorsan, egyszerre, megszakítás nélkül egy lélegzetre, egy szuszra, egy csapásra.

Kis távolságot, közelséget is jelölhetünk vele:

na jedan korak do/od čega ${ }^{20}$ - nagyon közel egy ugrásra, egy köpésre, egy kődobásnyira, egy köhajitásnyira.

\footnotetext{
${ }^{15}$ Egy fogra való sincs vmiből.

${ }^{16}$ Egy, de értékes/sokat érő.

${ }^{17}$ Egy betüvel.

${ }^{18}$ Egy pillanat alatt.

${ }^{19}$ Egy pillantás alatt.
} 
Az egyes szám, a 'valamivel megegyező' jelentésben, pontosabban a közös származás értelemben is használatos:

biti jedna krv i mleko ${ }^{21}$ - azonos apától és anyától származnak egy hús, egy vér vkivel

jedan list sa gore g2 $^{22}$. honfitárs, földi 2. azonos gondolkodású személy 3. hazai

jedne gore list ${ }^{23}$ - honfitárs, azonos gondolkodású személy biti jedna krv s kim ${ }^{24}$ - (vér)rokonsági kapcsolatban levő személyek.

A jedan a páros testrészekből álló egész része, illetve egyike is lehet: biti (stajati) jednom nogom u grobu ${ }^{25}$ - nagyon idős, beteg fél lábbal már a sírban van

zažmuriti/zažmiriti/prižmiriti na jedno oko/jednim okom/na dva oka ${ }^{26}$ - úgy tesz, mintha nem látna valamit, nem lenne róla tudomása, szándékosan nem lát, nem törődik vele szemet huny vmi felett jedno oko se smeje a drugo plače - az egyik szeme sír a másik nevet spavati na jedno uho ${ }^{27}$ - éberen, nyugtalanul alszik úgy alszik, mint a nyúl slušati na jedno uvo ${ }^{28}$ - 1. titokban kihallgat vmit, nagyon figyel csupa fül, hegyezi a fülét 2. szórakozottan, nem teljes figyelemmel követ csak fél füllel figyel/hallgat.

A magyarban a fél füllel hall azt jelenti, hogy pontatlan, megbízhatatlan módon jut a tudomására valami. Meggyőződést, valaminek az igaz voltában való hitet is kifejezheti, azt, hogy valami holtbiztos:

jasno kao jedanput jedan - világos, mint az egyszeregy

${ }^{20}$ Egy lépésre valamitől/valameddig.

${ }^{21}$ Egy vér és tej lenni.

${ }^{22}$ Egy levél az erdőből.

${ }^{23}$ Egy erdő levelei.

${ }^{24}$ Egy vére van valakivel.

${ }^{25}$ Egy lábbal a sírban áll/van.

${ }^{26}$ Behunyja az egyik szemét.

${ }^{27}$ Egyik fülére alszik.

${ }^{28}$ Az egyik fülére hallgatózik. 
A $d v a$ 'kettö' alapszóval képzett frazeológai egységeknek is nagyon különböző jelentésük, funkciójuk lehet. Képviselhetnek egy egészet, kevés mennyiséget, de többletet is. Az emberek közötti viszonyokban ez a szám két ellentétes relációt tükrözhet: egyrészt összhangot, nagy boldogságban, zavartalan szeretetben, békességben élést, de ugyanakkor ellentétet is kifejezhet, két különböző szemléletű, életvitelü ember közösségét:

živeti kao dva goluba ${ }^{29}$ - úgy élnek, mint a galambok

dva sveta $^{30}$ - két külön világ (vmi hasonló - ha már a világ fogalmánál szeretnénk maradni - mint az egy világ választ el valakit valakitöl magyar frazéma esetében).

Kifejezheti azt is, hogy valaki feltünően hasonlít valakire, illetve, hogy ketten nagyon hasolítanak egymásra. Érdekes módon a szerbben a kettő mellett a vízcseppet találjuk, azzal, hogy a magyar ekvivalensnek teljesen megfelelő formája is megtalálható a szerbben, de ott nem szerepel szám ${ }^{31}$ :

slični kao dve kapi vode ${ }^{32}$ - Úgy hasonlítanak egymásra, mint két tojás, olyanok, mint két tojás.

A kettes számot tartalmazó szerb frazémák között vannak olyanok is, amelyek az alany kedvezőtlen pozíciójára utalnak, arra, hogy az két fél, két ellentétes erő vagy érdekcsoport közötti helyzetbe került, amelyböl csak nagyon nehezen, vagy semmiképpen sem tud szabadulni:

biti/nalaziti se/naći se između dve vatre - kétszeres veszély fenyeget valakit, két oldalról támadják két tüz közé kerül

goreti na dva ognjalna dve vatre ${ }^{33}$ - 1. kétféle veszély között van 2. habozik, kételkedik

sedeti na/između dve stolice ${ }^{34}$ - 1. egyszerre két ellentétes félt támogat, kétszínüsködik kétkulacsos politikát folytat 2. mindkét dolgot magának akarja.

\footnotetext{
${ }^{29}$ Úgy élnek mint két galamb.

${ }^{30}$ Két világ.

${ }^{31}$ Liče kao jaje jajetu.

${ }^{32}$ Hasonlítanak mint két vízcsepp.

${ }^{33}$ Két tüzön ég.
} 
A magyar egy fenékkel/seggel két lovat ül meg/két nyeregben ül formális ekvivalensnek részben más a jelentése: 'egyidejűleg két olyan munkát végez, vagy két olyan állást tölt be, amelyek mindegyike egész embert kívánna, egyidejűleg két ellentétes követelésnek akar megfelelni’.

Elítélendő jellemre, arra hogy valaki kétszínü, képmutató, alakoskodó az alábbi szólás utal: tanjir od dva lica ${ }^{35}$ - kétszínű személy.

A kettő sok is lehet, több a vártnál, de ugyanakkor lehet valami nem kívánatos, mégis hasznot hozó:

imati dvije leve ruke - nagyon ügyetlen, bármihez fog, nem sikerül neki két bal keze van

sisati dve majke ${ }^{36}$ - több helyröl hasznot húzó

od jednog dinara napraviti dva (pet $)^{37}$ - nagyon sikeresen tud gazdálkodni vki, jól be tudja fektetni a tőkét, kamatoztatni tudja a tőkéjét.

Azonban a $d v a$ gyakrabban jelenthet keveset, elégtelent:

ne umeti ni dve unakrst ${ }^{38}$ - semmit sem tud, korlátolt szellemi képességü kettőig sem tud számolni

ne vredeti/ne valjati ni dve pare ${ }^{39}$ - nincs semmilyen értéke, értéktelen egy garast, fityinget sem ér

pala/spala knjiga na dva slova ${ }^{40}$ - szép lassan mind elfogytak, kevesen maradtak, akik valamilyen munkát ellátnak

braniti se (štititi koga i sl.) sa dva gola dlana ${ }^{41}$ - egyedül, puszta/meztelen kézzel védekezik, vagy valakit nagy áldozatok árán védelmez.

\footnotetext{
${ }^{34}$ Két széken ül.

${ }^{35}$ Két arcú/színü tányér.

${ }^{36}$ Két anyát szop.

${ }^{37}$ Egy dinárból kettőt csinál.

${ }^{38}$ Kettőt sem tud keresztbe (tenni).

${ }^{39}$ Egy parát sem ér.

${ }^{40}$ A könyvből két betü maradt.

${ }^{41}$ Két üres/csupasz/puszta tenyérrel védekezik / véd valakit.
} 
A kettes olyan helyzetet is jelölhet, aminek az érintett szempontjából lehet jó, de ugyanakkor rossz oldala is, arra utalva, hogy a dolgok ellenkező oldalát is meg kell vizsgálni:

batina ima dva kraja - az összetüzés jól, de rosszul is végződhet, az ellenfél visszavághat a botnak két vége van

mač $s$ dve oštrice - egyben jó és rossz következményekkel járó dolog, kellemetlen, veszélyes dolog kétélü fegyver

štap sa dva kraja - valami ami jól is, rosszul is elsülhet a botnak két vége van.

Összegező, rövid fogalmazásmódot is kifejezhet:

$u$ dve riječi - röviden egy-két szóban

reč $d v e^{42}$ - néhány szóban, rövid visszatekintés, röviden.

Rövid időtartamot jelöl a:

dan-dva-egy-két napig.

Közelségre, kis távolsára utal:

dva tri koraka-két-három lépésre.

Meggyőződést, valaminek a megbízható, szavahihető voltát fejezik ki az alábbi példák:

kao dva i dva četiri ${ }^{43}$ - teljesen egyértelmü, nyilvánvaló olyan biztos vmi, mint (az, hogy) kétszer kettö négy

kao dvaput dva [četiri] -olyan biztos vmi, mint (az, hogy) kétszer kettö négy.

A jedan és a $d v a$ szám egy szólásban a szerbben ritkán fordul elő, a már említett páros dolgok, testrészek megnevezésén kívül kiemeljük az alábbi példát, amelynek a magyarban is megvan az ekvivalense, és amely azt fejezi ki, hogy egy cselekvés kétszeres sikerhez vezethet, egy fáradsággal, cselekedettel kettős célt érhetünk el:

jednim udarcem [ubiti] dve muveldva zeca-két legyet üt egy csapásra.

\footnotetext{
${ }^{42}$ Egy két szót.

${ }^{43}$ Mint ahogy a kettő meg kettő az négy.
} 
A tri 'három' számot tartalmazó frazeológiai egységek leginkább a normától, a megszokottól, a várttól való eltérést fejezik ki. A három sokszor az optimálisnál kevesebbre, egyfajta hiányra, elégtelenségre, illetve valaminek a nem kívánatos jellegére utal:

biti na tri ćoška ${ }^{44}$ - rosszkedvü, kedvetlen, nincs jól, rossz állapotban van na tri ćoška $a^{45}$ - rosszul, összehangolatlanul, diszharmonikusan, kellemetlenül

čovek od tri knjige $e^{46}$ - tanulatlan vagy nagyon alacsony képzettséggel rendelkezö ember egykönyvü ember

ne znati brojati ni do tri $^{47}$ - buta, ügyetlen.

Ez valójában nagyon hasonlít a magyar olyan arcot vág, mint aki háromig sem tud számolni, vagy úgy néz ki, mint aki háromig sem tud számolni, csakhogy a magyarban a 'buta' mellett az 'ártatlan, jámbor, együgyü ember' benyomását is kelti.

nemati tri čiste $e^{48}$ - félénk, gyáva, ijedős ember

pala/spala knjiga na dva/na tri slova ${ }^{49}$ - szép lassan mind elfogytak, kevesen maradtak, akik valamilyen munkát ellátnak.

De a három néha elengendőt vagy sokat is jelenthet, a normánál, vagy elfogadhatónál többet:

svakog gosta tri dana dosta-akármilyen kedves vendég három napig untig elég

svako čudo za tri dana - minden csoda három napig tart

držati tri ćoška [kuće $]^{50}$ - a (házi)munka legnagyobb részét ellátja

kao da neko tri dana nije jeo ${ }^{51}$ - nagyon éhes, mintha három napig koplalt volna

jesti za tri čoveka - három helyett eszik

\footnotetext{
${ }^{44}$ Három sarkon lenni/ árom sarkú.

${ }^{45}$ Három sarkon.

${ }^{46}$ Három könyvből álló ember/három könyves ember.

${ }^{47}$ Háromig sem tud számolni.

${ }^{48}$ Nincs három tisztája.

${ }^{49}$ A könyvből három betü maradt.

${ }^{50}$ A ház három sarkát tartja.

${ }^{51}$ Mintha három napig nem evett volna.
} 
živeti za tri ćefa $a^{52}$ - szórja a pénzt, mulat.

A közelséget, vagy az összegező kifejezésmódot az alábbi példák illusztrálják:

dva tri koraka - nagyon közel három lépésre

reći dve tri - néhány szóban nyilatkozik, néhány szót szól két-három szót szól.

A četiri 'négy' a frazémákban leggyakrabban csukott térséget, belteret (a szoba, a ház falait) és a négy végtagot képviseli. A belső térben való tartózkodást mutatják az alábbi példák:

biti u svoja četiri zida ${ }^{53}$ - otthon van négy fal között

biti zatvoren, između četiri/u četiri [kućna/sobna] zida ${ }^{54}$ - nem hagyja el a házát, nem megy az emberek közé

sedeti između četiri zida ${ }^{55}$ - 1. nem megy ki a házból 2. börtönben van zatvoriti se u svoja četiri zida ${ }^{56}$ - visszavonul, nem megy az emberek közé živjeti između/među četiri zida ${ }^{57}$ - nem hagyja el a házát, nem kerül kapcsolatba más emberekkel, visszavonul a közéletből legati/leći među četiri daske ${ }^{58}$ - meghalt és koporsóba tették négy deszka közé tették.

A négyest a végtagok összeségeként az alábbi frazeologizmusokban találhatjuk meg:

dići sve četiri u zrak/uvis ${ }^{59}$ - lustálkodva lefekszik/ledől, lustálkodik ispružiti sve četiri $^{60}-1$. lefekszik, ledöl, lustálkodik 2. hirtlen elesik, rosszul esik

\footnotetext{
${ }^{52}$ Három kedve szerint él.

${ }^{53}$ A saját négy fala között van.

${ }^{54}$ A szoba/a ház négy fala közé van zárva.

55 Négy fal között ül.

${ }^{56}$ Bezárkózik a saját négy fala közé.

${ }^{57}$ Négy fal között él.

${ }^{58}$ Négy deszka közé feküdt.

${ }^{59}$ Mind a négyet a levegőbe emeli.

${ }^{60}$ Kinyújtja mind a négyet.
} 
na sve četiri (noge) ${ }^{61}$ - négykézláb, mászva

postaviti se na sve četiri ${ }^{62}$ - a négylábú állatok testhelyzetébe helyezi magát raskrečiti sve četiri kao žabac ${ }^{63}$ - kinyújtózkodik

otegnuti sve četiri ${ }^{64}$ - meghal, elhalálozik, megdöglik.

Negatív jellemábrázolásra szolgálnak az alábbi példák:

imati glavu za četiri noge $e^{65}-1$. okoskodik, okosnak teszi magát 2. buta, együgyü

ne umeti/ne znati ni četiri unakrst ${ }^{66}$ - nagyon buta, együgyü.

Intenzitást hivatottak kifejezni a következő szólások:

potkovati koga u sve četiri ${ }^{67}$ - teljes mértékben ellát, felszerel valakit valamivel

u sve četiri ${ }^{68}$ - teljes erővel, teljes mértékben

otvarati/otvoriti/uperiti sva četiri oka ${ }^{69}$ - nagyon vigyáz, figyel, különös figyelemmel kísér.

Érdekes módon a magyar példákban az, hogy valakinek négy szeme van, hogy négy szemmel néz/lát, nem azt jelenti hogy megkülönböztető figyelemmel követ valamit, hanem azt, hogy szemüveget visel. A szerb analógiájára a vajdasági magyar nyelvben azonban a fenti értelemben is használatos a kitárja a négy szemét.

A térség, illetve a benne történő mozgás korlátlanságára utal: na sve četiri strane $[\text { sveta }]^{70}$ - mindenütt, mindenhol.

A négyes előfordul olyan szólásokban is, amelyekben két személy szerepel:

\footnotetext{
${ }^{61}$ Mind a négyen (lábon).

${ }^{62}$ Mind a négyre leereszkedik.

${ }^{63}$ Szétterpeszti mind a négyet, mint a béka.

${ }^{64}$ Mind a négyet kinyújtja.

${ }^{65}$ Négy lábra való feje van.

${ }^{66}$ Négyet sem tud keresztbe tenni.

${ }^{67}$ Valakinek mind a négyét (végtagját) megpatkolja.

${ }^{68}$ Mind a négyben.

${ }^{69}$ Kinyitotta/kitárta mind a négy szemét.

${ }^{70}$ A világnak mind a négy táján.
} 
u/među četiri oka - tanú nélkül, kettesben négyszemközt.

A četiri, mint két kettes összege vagy szorzata, nagyfokú meggyőződés kifejezésére szolgáló frazémákban is szerepel:

kao dva i dva četiri ${ }^{71}$ - biztosan, mindenképpen, megbízhatóan

kao dvaput dva [četiri] - biztosan, nyilvánvalóan olyan biztos valami, mint (az, hogy) kétszer kettö négy.

A pet 'öt' számot tartalmazó szerb szólásokban ez a szám rövid időtartamot (általában 5 percet), kitünő osztályzatot, kis mennyiséget, kisfokú gyorsaságot stb. jelent. Az ötperces időtartam rövid ugyan, de sokszor nagyon jelentős lehet az egyén életében, erre utalnak az alábbi szólások:

dolazi/nastupa čijih pet minuta ${ }^{72}$ - eljön az alkalom, hogy valaki megmutassa a képességeit, eljön valaki számára a nagy lehetőség dočekati svojih pet minuta ${ }^{73}$ - megérte azt, hogy megmutathassa képességeit, elérkezett a siker elérésének kedvező pillanata imati svojih pet minuta ${ }^{74}$ - a legjobb fényben mutatkozik (kihasználva a kedvező alkalmat).

Itt kell megemlíteni, hogy a magyarban is létezik egy szólás, a rájön valakire az ötperc, amelynek teljesen negatív jelentése van, és nem hozható párhuzamba a fenti példákkal. Azt jelenti ugyanis, hogy valaki hisztériázik, idegrohamot kap.

Amennyiben az ötös iskolai osztályzatként szerepel, akkor az értékrend legmagasabb fokán helyezkedik el:

za pet $^{75}-1$. kiemelkedő, kitünő 2 . kiemelkedően, kitünően.

A pet értéktelen ha kis pénzegység előtt fordul elő:

ne dati za što, za koga ni pet para $^{76}$ - valamit egyáltalán nem értékel, elértéktelenít

\footnotetext{
${ }^{71}$ Mint ahogy a kettő plusz kettő az négy.

${ }^{72}$ Elérkezik valaki öt perce.

${ }^{73}$ Kivárta a saját öt percét.

${ }^{74}$ Van saját öt perce.

${ }^{75}$ Ötösért.
} 
ne vrijediti (ne valjati) ni pet para $^{77}$ - jelentéktelen, értéktelen nem ér valami egy petákot sem.

Valamely cselekvés, történés gyors lefolyását, időbeli gyorsaságot illusztrálnak az alábbi példák:

ni pet ni devet ${ }^{78}$ - azonnal, habozás, gondokodás nélkül

ni pet ni šest ${ }^{79}$ - rögtön, azonnal, gondolkodás nélkül

pet na devet ${ }^{80}$ - sebtében, kapkodva, futólag.

Hogy kevés idő maradt hátra, a közvetkező szólás fejezi ki:

pet minuta pre/do dvanaest ${ }^{81}-$ az utolsó pillantaban, végső ideje.

Azt, hogy valaki valakit vagy valamit jól ismer, a kéz öt ujjával hozható kapcsolatba:

znati (poznavati) koga, što kao svojih pet prstiju ${ }^{82}$ - nagyon jól, alaposan, a legapróbb részletekig ismer valakit/tud valamit ismeri mint a tenyerét.

A magyarban csak tárgyra vagy térségre vonatkoztathatjuk az úgy tud/ismer mint az öt ujját szólást. A pet negatív konnotációjú az alábbi példában:

ne znati brojati ni do pet $^{83}$ - nagyon buta, ügyefogyott.

Az ötös és a kilences kombinálása csalásra, vagy pedig tréfára enged következtetni az alábbi példákban:

dati kome pet za devet ${ }^{84}$ - becsap, rászed valakit

ne znati pet na devet ${ }^{85}$ - nem ismer tréfát, hirtelen természetü

\footnotetext{
${ }^{76}$ Valakiért/valamiért öt parát (fillérnek megfelelő egység) sem ad.

${ }^{77}$ Nem ér öt parát sem.

${ }^{78}$ Se öt, se kilenc.

${ }^{79} \mathrm{Se}$ öt, se hat.

${ }^{80}$ Öt a kilencen.

${ }^{81}$ Öt perccel tizenkettő/dél előtt.

${ }^{82}$ Úgy tudja/ ismeri, mint az öt ujját.

${ }^{83}$ Ötig sem tud számolni.

${ }^{84}$ Valakinek ötöt ad kilencként.
} 
nema kod koga pet na devet ${ }^{86}$ - nem ismer tréfát, hirtelen természetü.

A sedam 'hét' általában titokzatosságot, de ugyanakkor intenzitást, hosszabb időszakot és nagyobb távolságot is jelent a szerb frazeológiában. Ha valaki nagyon ügyes, ravasz, körmönfont, agyafúrt, a szerbben többek között azt szokták mondani:

biti namazan/premazan sa sedam masti ${ }^{87}$ - nagyon ravasz, agyafúrt, mindenféle csalásra képes minden hájjal meg van kenve.

Titokzatosságra, eltitkolásra utalnak az alábbi példák:

knjiga sa sedam/devet pečata ${ }^{88}$ - kifürkészhetetlen, megismerhetetlen, felfoghatatlan, nagy talány hétpecsétes titok

pismo sa sedam pečata ${ }^{89}$ - olyan levél, amelynek tartalmát legnagyobb titok övezi

zatvoriti se pred kim sa sedam ključeva ${ }^{90}$ - nem árulja el a véleményét zatvoriti/zabraviti što sa sedam lokota ${ }^{91}$ - jól elzár hét lakat alatt őriz, hét lakat alatt van.

A magyar ekvivalensnek a szerb jelentésen kívül (ti. hogy 'vmi nagyon biztonságosan, hozzáférhetetlenül el van zárva, mert nagyon féltik') van még egy másik értelme is, hogy 'valakit börtönben öriznek'.

Hosszú időszakot jelöl a hetes az alábbi bibliai vonatkozású példákban: sedam gladnih krava ${ }^{92}$ - többéves éhínség, rossz termésű időszak (a bibliai hét szük esztendőre utalva)

sedam gladnih godina - hét szük esztendö.

\footnotetext{
${ }^{85}$ Nem tud ötöt a kilencre.

${ }^{86}$ Nincs valakinél öt kilenc helyett.

${ }^{87}$ Hét zsírral meg van kenve.

${ }^{88}$ Hét/kilenc pecsétes könyv.

${ }^{89}$ Hétpecsétes levél.

${ }^{90}$ Hét kulccsal elzárkózik valaki elől.

${ }^{91}$ Hét lakat mögé zár.

${ }^{92}$ Hét éhes tehén.
} 
Nagy távolságot, messzeséget jelöl a mesékben található fordulat is: preko sedam brda ${ }^{93}$ - nagyon messze hetedhét országon/határon is túl.

A már említett kombináción kívül, amikor a kilenc az öttel párosul, a devet 'kilenc' önállóan is előfordul. Ilyenkor ugyanis valaminek a fokozását, továbbá térbeli és időbeli távolságot fejez ki, valamint biztonságot is jelent:

devet znojeva ${ }^{94}$ - nagy gond, baj, erőfeszítés, igyekezet naokolo na devet konaka ${ }^{95}$ - messzire preko devet brda $a^{96}$ - nagyon messze hetedhét országon túl od devet dedova/deda ${ }^{97}$ - nagyon régóta zavezivati što u devet čvorova ${ }^{98}$ - nagyon félt valamit.

A deset 'tíz' a frazeológiai egységekben elsősorban az ujjak számát jelöli mindkét kézen, de áldozatos munkát és nagy igyekezetet is ki lehet vele fejezni:

sa svojih deset nokata - saját munkájával, igyekezetével, bármilyen segítség nélkül a tíz körmével

sa svojih deset prsta/prstiju ${ }^{99}$ - saját munkájával, igyekezetével, bármilyen segítség nélkül.

Időviszonyt is kifejez egy példában, amikoris 10 éves időszakot jelöl: baciti s leđa deset (dvadeset i dr.) godina ${ }^{100}$ - megfiatalodik, tíz (húsz) évvel fiatalabbnak néz ki.

\section{SORSZÁMOK A SZERB FRAZEOLÓGIÁBAN}

A prvi 'első' sorszám a szerb frazeológiában gyakran valaminek a jelentőségét hangsúlyozza, illetve annak minőségét, pozitív jellemzőit:

\footnotetext{
${ }^{93}$ Hét hegyen túl.

${ }^{94}$ Kilenc izzadság.

${ }^{95}$ Kilenc napi járóföldre.

${ }^{96}$ Kilenc hegyen túl.

${ }^{97}$ Kilenc nagyapán keresztül.

${ }^{98}$ Kilenc(szeres) csomóba köt.

99 A saját tíz ujjával.

${ }^{100}$ Tíz (húsz) évet dob le a hátáról.
} 
biti prva violina - valamely közösségben vezető szerepe/beosztása van, döntően befolyásolja azt első hegedüs

biti prvoga reda - a legjelentősebb, a jelentősége/értéke tekintetében első helyen áll elsörendü

biti/stajati u prvim redovima - 1. kitünik, a legkimagaslóbb helyen, rangos poszton, az elsők között van 2. veszélynek teszi ki magát $a z$ elsö sorban/az élvonalban van

biti u prvom planu - kiemelkedő, jelentős helyen van, első helyen, elötérben van

izbiti/doći/iskočiti/izići u prvi plan ${ }^{101}$ - elfoglalja a legjelentősebb, kiemelkedö helyet

staviti/postaviti što u prvi red ${ }^{102}$ - valamit nagyon fontosnak tart, fö céljaként jelöl meg

prve klase - kitünő, kiemelkedő, a legjobb elsö osztályú, elsőrendü

voditi/imati/držati prvu reč - 1. a legnagyobb befolyással rendelkezik, jelentős dolgokban dönt 2. a figyelem központjában van, többet beszél a többinél viszi a szót

svirati prve gusle ${ }^{103}$ - valamiben a legfontosabb, legbefolyásosabb személy. A 'guzlica' szerb népi hangszer, ezért használják a hegedủ alternációjaként, azonos jelentésben.

Az első gyakran jelentkezik valamilyen kezdetet kifejező szólások esetében:

prvi korak/koraci - a kezdet, kezdeményezés, valaminek az első időszaka (az életben, tevékenységben, munkában) elsö lépés na prvom koraku ${ }^{104}$ - a kezdet kezdetén, mindjárt az elején učiniti prvi korak - megkezdi a munkát, müködni kezd, közelít férfihoz, vagy nöhöz, ismerkedést kezdeményez megteszi az első lépést prvi mrak ${ }^{105}$ - alkonyodni kezd

\footnotetext{
${ }^{101}$ Előtérbe kerül.

${ }^{102}$ Az első sorba állít.

${ }^{103}$ Az első guzlicán játszik.

${ }^{104} \mathrm{Az}$ első lépés során.

${ }^{105}$ Első sötétség.
} 
prva lasta - elöljáró, élen járó, úttörő, az első jele valaminek első fecske gde je koga prvo sunce ogrejalo ${ }^{106}$ - ki hol született zaorati/povući prvu brazdu ${ }^{107}$ - elsőként, úttöröként megkezd valamilyen jelentősebb munkát vagy építkezést megteszi az első kapavágást na prvom mestu ${ }^{108}$ - elöszöris, mindenekelött u prvi čas - kezdetben az elsö pillanatban u prvi $\mathrm{kraj}^{109}$ - valaminek mindjárt a kezdetén, kezdetben u prvi tren/u prvom trenu ${ }^{110}$ - elöbb, eleinte u prvom redu-mindenekelött, első helyen za prvu ruku ${ }^{111}$ - kezdetnek.

'Kora reggel' jelentéssel bírnak az alábbi szólások:

u prve petlove $e^{112}$ - kora hajnalban, amikor az első kakasok megszólalnak do prvih petlova ${ }^{113}$ - kora hajnalig.

A közvetlenül, első forrásból való információszerzésre a szerbben két frazéma is létezik:

čuti što iz prvih usta ${ }^{114}$ - az első forrásból értesül iz prve ruke - közvetítő nélkül, közvetlenül első kézből.

Gyorsaságra, hanyagságra, felületességre utalnak: na prvi pogled - azonnal, amint megpillantja, felületes áttekintés után, anélkül, hogy belemélyedne elsö pillantásra, elsö látásra na prvu loptu ${ }^{115}$ - rögtön, gondolkodás nélkül.

\footnotetext{
${ }^{106}$ Kit hol melegített meg a nap először.

${ }^{107}$ Megszántja/meghúzza az első barázdát.

${ }^{108}$ Első helyen.

${ }^{109} \mathrm{Az}$ első végben.

${ }^{110}$ Az első pillanatban.

${ }^{111}$ Első kéznek.

112 Az első kakasszókor.

${ }^{113}$ Az első kakasszóig.

${ }^{114}$ Az első szájból hallani.

${ }^{115}$ Az első labdára.
} 
$\mathrm{Az}$ első nehézségeken való átjutás ecsetelésére is alkalmas a prvi sorszámmal alkotott szólás:

pregrmeti prvu vatru ${ }^{116}$ - túl van az első megpróbáltatásokon, átvészeli az első nehézségeket.

A 'fiatalság' főnévvel együtt tagadó szerkezetben azt jelenti, hogy valaki idősebb lett:

ne biti u prvoj mladosti - nem fiatal már, elörehaladott korban van, túl van az első ifjúságán.

Kezdeti nagy sikerről vall az alábbi szólás a szerbben:

prvo pa $m u s ̌ k o{ }^{117}$ - első nekifutásra mindjárt sikert arat.

Azt, hogy már nem túl éhes valaki, szintén az első sorszámot tartalmazó frazémával fejezik ki a szerbben:

utoliti/utišati prvu glad ${ }^{118}$ - eszik egy keveset, hogy csillapítsa az éhség kellemetlen érzetét.

A drugi 'második' sorszám a frazémákban a különbséget, a másságot hivatott érzékeltetni:

biti drugoga kova ${ }^{119}$ - másmilyen, másfajta, különbözik a többitől

druge gusle $e^{120}$ - valami más, valami új

gledati drugim očima ${ }^{121}$ - más véleményen van más megvilágításban lát vmit

gledati kroz druge naočari ${ }^{122}$ - másként vélekedik valamiről, másként tekint valamire

to je druga priča - ez egészen más ez más történet

to je drugi padež ${ }^{123}-$ ez más tészta

\footnotetext{
116 Átvészeli az első tüzet.

${ }^{117}$ Első, méghozzá fiú/férfi.

118 Enyhíti első éhségét.

${ }^{119}$ Másmilyen veretü.

${ }^{120}$ Második guzlica.

${ }^{121}$ Más szemmel néz/lát valamit.

${ }^{122}$ Más szemüvegen keresztül szemlél valamit.
} 
to je druga stvar ${ }^{124}$ - ez valami más

to su druge diple ${ }^{125}$ - ez más nóta

u drugom svetlu ${ }^{126}$ - a megszokottnál, a tapasztaltnál másként más fényben lát vkit/vmit

u drugu ruku ${ }^{127}$ - másrészröl, különben, egyébként, más megvilágításban.

Gyakran képez olyan frazelógiai egységeket, amelyek valamilyen változást érzékeltetnek:

biti/osećati se kao drugi čovek ${ }^{128}$ - mintha újjászületett volna, felfrissült drugu реsтu pevati - megváltoztatja az addigi eljárást, másként dolgozik/gondolkodik/ beszél egészen más nótát fúj

dunuo jelduva drugi/novi vetar - megváltoztak a körülmények más szelek fújnak

okrenuti drugi $\mathrm{kraj}^{129}$ - homlokegyenest megváltoztatja viselkedését, álláspontját, ellenkező módon cselekszik

okrenuti/obrnuti drugi list ${ }^{130}$ - az addigiaknál másképpen kezd cselekedni, a bevett szokásoktól eltérően, megváltoztatja viselkedését, valami újba kezd tiszta lapot nyit

skrenuti na drugu stazu ${ }^{131}$ - megváltoztatja valaminek a tartalmát/lényegét/értelmét

učiniti/stvoriti od koga drugog čoveka ${ }^{132}$ - teljesen megváltoztat valakit, jobbá teszi embert farag valakiböl

udariti u druge žice/u drugu žicu - a szerbben ez a szólás azt jelenti, hogy más, ellenkező állást foglal, míg a magyar azonos szerkezetủ más húrokat penget valamivel más értelmü 'más, szelídebb

\footnotetext{
${ }^{123}$ Más eset.

${ }^{124}$ Ez más dolog.

${ }^{125}$ Ez más kétsípú duda.

${ }^{126}$ Más fényben.

${ }^{127}$ Más kézből.

${ }^{128}$ Másmilyen embernek érzi magát.

${ }^{129}$ Megfordítja a másik végét. Másik végét veszi elő.

${ }^{130}$ Másik lapot fordít/hajt.

${ }^{131}$ Más útra térít.

${ }^{132}$ Más embert csinál belőle.
} 
hangnemben beszél, tárgyal valakivel, más vagy szelídebb eszközhöz folyamodik, hogy hatni tudjon' uhvatiti se na drugu banderu ${ }^{133}$ - oldalt, pártot, államot változtat udarati/udariti/zasvirati u druge diple ${ }^{134}$ - nem áll ki valaki mellett, más álláspontra helyezkedik, másmilyen állásponton van

udarati/udariti/guditi/zaguditi u druge gusle ${ }^{135}$ - másként kezd beszélni, viselkedni.

Valami kevésbé fontos dolgot is kifejezhet:

biti druga/treća violina - alárendelt, kevésbé fontos a szerepe csak másodhegedüs

svirati drugu violinu - csak mellékszereplö, kevésbé fontos a szerepe csak másodhegedüs

biti u drugom planu - kevésbé fontos, mellékes a háttérben van staviti/potiskivati/potisnuti što u drugi plan - elhalaszt, elhanyagol valamit, mellékesnek tart, nem tulajdonít neki nagy jelentőséget háttérbe szorit.

Tagadással együtt egyfajta megmásíthatatlan tényállást fejez ki, valamilyen feltétlen igazságot:

drugog boga nema ${ }^{136}$ - így van ahogy van, a tényállást nem lehet megváltoztatni, más nem marad hátra

nema druge/nije druge $e^{137}$ - nincs választási lehetőség, nincs kiút

nije komu ostalo [ništa] drugo ${ }^{138}$ - nincs más megoldás, másként nem lehet, így muszáj.

Az információszerzés közvetett módjára utal az alábbi két szólás:

čuti nešto iz drugih usta ${ }^{139}$ - más forrásból, valaki közvetítésével hallotta

\footnotetext{
${ }^{133}$ Másik póznát ragad meg.

${ }^{134}$ Más kétsípú dudát kezd fújni.

${ }^{135}$ Más guzlicán kezd játszani.

${ }^{136}$ Másik Isten nem létezik.

${ }^{137}$ Nincs más.

${ }^{138}$ Más nem marad hátra.

${ }^{139}$ Más szájakból/ajkakról hallotta.
} 
iz druge ruke $e^{140}$ - közvetítőn keresztül másodforrásból.

A drugi svet 'másvilág' a szerbben is a túlvilágot, illetve halált szimbolizálja:

drugi svet - másvilág

otići/poći/preseliti se na drugi svet - meghal átköltözik a másvilágra poslati/otpratiti/spraviti/ukloniti koga na drugi svijet - meggyilokol a másvilágra küld, átsegít a másvilágra.

A drugi sorszám 'másmilyen kifejezésmód' jelentést is kölcsönözhet a szerkezetnek, amely lehet világos, de zavaros is:

drugim rečima - másképp fogalmazva másszóval

početi/zaći s drugoga kraja ${ }^{141}$ - megváltoztatja a beszéd fonalát, kertel, hímez-hámoz

skakati s jednoga kraja na drugi ${ }^{142}$ - összevissza, összefüggéstelenül beszél čas jedno čas drugo ${ }^{143}$ - összevissza, találomra, vaktában.

A drugi valami kívánatos, pozitív dolgot is jelenthet:

druga mladost $1^{144}$ - öregkori életerö

druga obala ${ }^{145}$ - igazi, óhajtott dolog, olyan hely, ahova kívánkozunk

druge bi komu ptice [danas] pevale ${ }^{146}$ - valaki máshol, jobb körülmények

között lenne.

Az előzővel ellentétben valamilyen negatív, nem kívánatos dolgot is kifejezhet:

čuti druge gusle $e^{147}$ - más, rosszabb dolgokat tapasztalt

druga strana medalje -a dolgok igazi, negatív színe az érem másik oldala.

\footnotetext{
${ }^{140}$ Másodkézből.

${ }^{141}$ A másik végéről kezdi.

${ }^{142}$ Az egyik végéről a másikra ugrál.

${ }^{143}$ Hol az egyik, hol a másik.

${ }^{144}$ Második fiatalság.

145 A másik part.

${ }^{146}$ Ma más madarak énekelnének neki.

${ }^{147}$ Más guzlicát hallott.
} 
A drugo stanje kifjezés a nő másállapotát, a terhességet jelenti:

biti u drugom stanju - állapotos, terhes.

S végül, az alábbi szerkezetben a drugi sorszám tulajdon-, birtokváltásra utal: prelaziti/preći u druge ruke-más kezébe kerül.

A treći 'harmadik' sorszám a másodikhoz hasonlóan szintén valami jelentéktelen dolgot vagy személyt szokott jelenteni:

biti (druga) treća violina ${ }^{148}$ - mellékes szerepe, harmadrendű jelentősége van.

A közvetett információszerzésre is használják a szerbben:

čuti što iz trećih usta ${ }^{149}$ - mástól hallotta, gyakran megbízhatatlan forrásból iz treće ruke - harmadkézböl.

Tulajdonos-, birtokosváltást is kifejezhet, akár a második:

prelaziti/preći u treće ruke - harmadkézbe jut.

A treći fölösleges személyt jelent az alábbi szókapcsolatban:

tréci čovek ${ }^{150}$ - szerető.

A fenti példához hasonlóan, a peti 'ötödik' is lehet fölösleges vagy zavaró dolog, illetve személy, valami ami szükségtelen vagy jelentéktelen:

biti peti točak [u kolima] - ötödik kerék

mariti za koga kao pas za petu nogu ${ }^{151}$ - egyáltalán nem törődik vele, nem bánja.

A hadoszlop jelentésủ kolona fónévvel hazaárulókat jelent:

peta kolona - a külső ellenfél hazai fizetett segítői ötödik hadoszlop

\footnotetext{
${ }^{148}$ Harmadik hegedüs.

${ }^{149}$ Harmadik szájból hallotta.

${ }^{150}$ Harmadik ember.

${ }^{151}$ Törődik valakivel, mint a kutya az ötödik lábával.
} 
Csak egy példában van az ötödik sorszámnak pozitív értelmezése, éspedig valami nagyon jelentőset fed:

peto jevanđelje ${ }^{152}$ - szentség, nagyon jelentős dolog.

A szókapcsolatokban szereplő sedmi 'hetedik' sorszám rendszerint valami mellékes, fölösleges dologgal hozható kapcsolatba:

sedma svirala ${ }^{153}$ - ami jelentéktelen, mellékes

rođak u sedmom kolenu ${ }^{154}$ - nagyon távoli rokon, nem is rokon.

Az érzelmi állapotok vagy megnyilvánulások intenzitását hivatott kifejezésre juttatni a sedmi sorszám az alábbi példákban:

biti na/u sedmom nebu ${ }^{155}$ - a hetedik mennyországban van euforikus hangulatban van, nagyon boldog

derati se do sedmoga znoja ${ }^{156}$ - nagyon hangosan kiabál, a végkimerülésig üvöltözik.

A sila 'erő, hatalom' főnévvel alkotott állandósult szókapcsolat a sajtóra vonatkozik:

sedma sila ${ }^{157}$ - a sajtó, újságírók.

Az osmi 'nyolcadik' sorszámmal csak egy szólás fordul elő a szerb frazeológiai szótárakban, s ennek pontos ekvivalensét megtaláljuk a magyarban is:

osmo svetsko čudo - 1 . egyedülállóan csodálatos dolog 2 . már ismert, dolog, amit csodaként emlegetnek a világ nyolcadik csodája.

Annak érzékeltetése, hogy valami jelentéktelen, említésre sem méltó, a deveti 'kilencedik' sorszámmal alkotott frazeológiai egységekkel is lehetséges a szerbben: deveta stvar ${ }^{158}$ - teljesen mellékes, lényegtelen dolog

\footnotetext{
152 Ötödik evangélium.

${ }^{153}$ Hetedik pásztorsíp.

${ }^{154}$ Hetedfokú rokon.

${ }^{155}$ A hetedik égen van.

${ }^{156}$ A hetedik izzadtságig üvölt.

${ }^{157}$ Hetedik hatalom.

${ }^{158}$ Kilencedik dolog.
} 
deveta rupa na svirali ${ }^{159}$ - 1. értéktelen, jelentéktelen, mellékes dolog 2. jelentéktelen ember, olyan, akit környezete nem becsül devete pete zveketalo ${ }^{160}$ - teljesen értéktelen dolog, tárgy biti deveti/peti/sedmi u plugu ${ }^{161}$ - fölösleges, szükségtelen, jelentéktelen, értéktelen.

Ahogyan a hetedik sorszámmal, a kilencedikkel is ki lehet fejezni a távoli rokonságot, vagy azt, hogy nem áll fenn a rokonsági viszony:

deveta voda kisela ${ }^{162}$ - vagy nagyon távoli, vagy semmilyen rokonság devete peći žarilo/omelo ${ }^{163}$ - szegröl-végröl rokon rođak u devetom kolenu ${ }^{164}$ - nagyon távoli, vagy semmilyen rokon šimširova grana sa devete gore ${ }^{165}$ - nagyon távoli rokon.

Az alábbi példában a mély álmot, az álom intenzitását fokozza a sorszám: buditi se/probuditi se iz devetog sna ${ }^{166}$ - nehezen ébredezik, hosszadalmas alvás után ébred.

Ha valaki nagyon szokatlanul néz ki, furcsa a megjelenése, azt többek között a deveti sorszámot tartalmazó szólással is ki tudják fejezni:

izgledati kao deveto čudo ${ }^{167}$ - szokatlanul, furcsán néz ki.

Akár a sedmi sorszámmal képzett frazémák esetében, úgy a deveti is közrejátszott a jó hangulatot kifejező szólás megalkotásában:

biti na/u devetom nebu ${ }^{168}$ - euforikus hangulatban van, nagyon boldog.

\footnotetext{
${ }^{159}$ Kilencedik lyuk a pásztorsípon.

${ }^{160}$ Kilencedik sarok kereplöje.

${ }^{161}$ Kilencedik/ötödik/hetedik az ekében.

162 Kilencedik savanyú víz/ásványvíz.

${ }^{163}$ Kilencedik kemence/kályha piszkafája (pemetéje).

${ }^{164}$ Kilencedik ízigleni rokon.

165 Buxuság a kilencedik hegyről.

${ }^{166}$ A kilencedik álmából ébred.

${ }^{167}$ Úgy néz ki, mint a kilencedik csoda.

${ }^{168}$ A kilencedik égen van.
} 
A deseti 'tizedik' sorszámmal alkotott szókapcsolatok jelenthetik valaminek a jelentéktelen voltát, ezenkívül különbözőséget, másságot is:

nešto deseto ${ }^{169}$ - valami egészen más, eltérő

obrnuti/okrenuti razgovor na [sasvim] deseto ${ }^{170}$ - teljesen más dologra hívja fel a figyelmet.

Végül meg kell említeni, hogy egyes főnevekhez a frazeológiai egységekben különböző sorszámok járulhatnak. Ilyenek például a briga 'gond', daska 'deszka', banka 'bankó, bankjegy', pevac 'kakas' szavak:

deseta/deveta/poslednja/sedma/šesta briga ${ }^{171}$ - jelentéktelen, mellékes nemati treće/četvrte daske [u glavi $]^{172}$ - együgyü, buta, ügyefogyott, tökkelütött, hibbant

razmeniti treću/četvrtu itd. banku $u^{173}$ - élete harmincas/negyvenes stb. éveibe lép, belép a harmadik/negyedik évtizedébe

u prve/druge/treće pevce ${ }^{174}$ - hajnalok hajnalán (amikor a kakasok kora hajnalban először, másodszor vagy harmadszor kukorékolnak).

\section{ÖSSZEGZÉS}

Dolgozatunkban a számneveket tartalmazó szerb szólásokat vizsgáltuk meg kontrasztív nyelvészeti szempontból, a magyarral összevetve. A szerb frazeológiai egységekböl kiindulva, először megadtuk azok magyar jelentését, majd amennyiben léteznek - az ekvivalens magyar szólásokat is feltüntettük.

Annak ellenére, hogy a magyar nyelvben is sok olyan szólás van, amelynek vezérszavát számnév képezi, elemzésünk során megállapítottuk, hogy a szerkezeti és jelentésbeli azonosságot mutató frazémákon kívül sok szerb szólásnak nincs formai ekvivalense a magyarban, illetve hogy a szemantikai ekvivalenicát gyakran lexikai módosításokkal lehet elérni. A kutatás eredményei igazolják előzetes

\footnotetext{
${ }^{169}$ Valami tizedik.

${ }^{170}$ Tizedik dologra terelni a beszélgetést.

171 Tizedik/kilencedik/utolsó/hetedik/hatodik stb. gond.

${ }^{172}$ Nincs harmadik/negyedik deszkája (a fejében).

${ }^{173}$ Felváltja a harmadik/negyedik stb. bankóját. Itt a bankó tízest jelent.

${ }^{174}$ Az első/második/harmadik kakasszóra.
} 
feltételezésünket, miszerint a frazeológia-alkotásban léteznek ugyan univerzális mechanizmusok, de jelentős szerep jut a hagyománynak és a kultúrának is.

Andrić Edita, Dušanka Zvekić Dušanović

\section{NUMBER-BASED PHRASEOLOGICAL UNITS IN SERBIAN AND HUNGARIAN}

\section{Summary}

The paper explores Serbian phraseological units which include a number, with the aim of finding their Hungarian equivalents or, if no equivalent is available, providing a literal translation. In addition, we emphasize certain semantic features of the phraseologisms, on the basis of which we categorise these units. The analysis of the data reveals that while a number of Serbian phrasemes have formally and semantically identical equivalents in Hungarian, there is also a large number of units which have no formal correspondents in Hungarian and semantic equivalence can thus often be achieved by means of lexical modification. The results of the study confirm our preliminary assumption that while clearly there are universal mechanisms at work in phraseology, tradition and culture also play a very important role.

Keywords: phraseology, numbers, Serbian, Hungarian

\section{BROJ U SRPSKOJ I MAĐARSKOJ FRAZEOLOGIJI}

\section{Sažetak}

Pošavši od srpskih frazeologizama u čijem se sastavu pojavljuje broj kao leksička jednica u radu smo najpre dale njihova značenja na mađarskom jeziku, a zatim i ekvivalentne mađarske frazeologizme, ukoliko je utvrđeno njihovo postojanje. Osim toga, dati su i njihovi doslovni prevodi. Uprkos činjenici da je mađarski jezik bogat frazeološkim izrazima s numeričkom komponentom, pokazalo se da, pored postojanja onih frazelogizama u kojima se može ustanoviti formalno semantička podudarnost, znatan broj ove grupe srpskih izraza nema svoj formalni ekvivalent u mađarskom, odnosno da se semantička ekvivalencija često može postići izvesnom modifikacijom leksičkog sastava. Ovaj rezultat potvrđuje početnu pretpostavku o postojanju univerzalnih mechanizama u formiranju frazeologizama, ali i značajnu ulogu tradicije i kulture u pojedinačnim jezicima.

Ključne reči: frazelolgija, brojevi, srpski jezik, mađarski jezik

\section{IRODALOM}

Ajdačić, Dejan, Lidija Nepop Ajdačić (2015). Poredbena srpsko-ukrajinska frazeologija. Beograd: Alma. 
Bárdosi Vilmos (2012). A magyar szólások, közmondások értelmezö szótára fogalomköri szómutatóval. Budapest: Tinta Könyvkiadó.

Fink, Željka (1989). Frazeologizmi s numeričkom komponentom (na materijalu hrvatskih ili srpskih i ruskih frazeologizama). Radovi Zavoda za slavensku filologiju, Zagreb, 24, 81-96.

Forgács Tamás (2003). Magyar szólások és közmondások szótára. Budapest: Tinta Könyvkiadó.

Matešić, Josip (1982). Frazeološki rječnik hrvatskoga ili srpskog jezika. Zagreb: Školska knjiga.

Mršević-Radović, Dragana (1994). Broj više u frazeologiji. Folklor u Vojvodini sv. 8. Novi Sad: Udruženje folklorista Vojvodine. 110-119.

RSJ - Nikolić, Miroslav (szerk.) (2007). Rečnik srpskoga jezika. Novi Sad: Matica srpska.

Otašević, Đorđe (2012). Frazeološki rečnik srpskog jezika. Novi Sad: Prometej.

Štrbac, Gordana (2019). Frazeološka jedinica i pristupi njenom izučavanju. Naučni sastanak slavista u Vukove dane 48/1: 259-269. 